\title{
Developmental Challenges for 21st Century
}

\author{
V. Vijay Anand Sriram
}

Abstract--- Preparing our self for changes and challenges will keep us active, alive, artistic and authoritative. The first step before preparation is discussion and initiation. This paper aims at analyzing various developmental changes faced by our country and aims a developing a practical approach to address this issues and aim at implementable solutions, with prime focus on value based approach

Keywords--- Challenges, Human Resources, Values, $\mathrm{Hr}$ Culture

\section{DEVElopment Challenges For 21ST CENTURY}

\section{A. From Perspective of Human Resources}

DREPARING our self for changes and challenges will keep 1 us active, alive, artistic and authoritative. The first step before preparation is discussion and initiation. I am very happy to note that, today's event throws highlight on this important chapter of our life, yes our perspective and ability to accept challenges and changes towards 21 st century.

B. Where we are?

1. Technological Development at a RAPID Phase

2. Human Resource Development Motivated to compete Technological development

3. Increase in Competition at all levels

4. Decrease in values and morals of people at level

5. Uncertainity and Insecurity a feeling of alienation and isolation because of long work hours

Table 1[1]: Interesting Statistics

\begin{tabular}{|l} 
IMPORTANT ACHIEVEMENTS \\
Quantitative Expansion \\
The following comparative data show the remarkable growt \\
of Indian Education since India became a republic in 1950: \\
S $\quad$ ITEM \\
STATISTICS \\
1. Literacy Rate \\
2. \\
3.
\end{tabular}

6. Nuclear families giving rise low interpersonal relationship and anxiety

7. Phenomenal Growth in Education Sector

V. Vijay Anand Sriram, Research Scholar, DOMS, SCSVMV Deemed University, Enathur, Kanchipuram. E-mail: vasphd@gmail.com

8. Increase in average income of individuals

9. Certain strata of society still struggling for survival

10. Increase in purchase power among people

11. Globalization and Liberalization at its peak and India one of the most preferred partner for any ventures

\section{Human Perspective of Economy}

What's your organization's outlook for 2010 given the current economy?

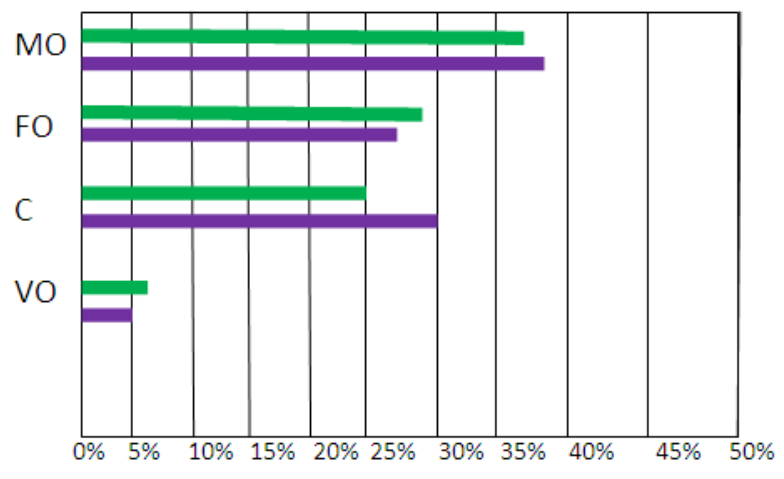

$$
\begin{aligned}
& \text { MO - Mildly Optimistic } \\
& \text { FO - Fairly Optimistic } \\
& \text { C-Cautious } \\
& \text { VO-Very Optimistic }
\end{aligned}
$$

YEAR 2009

YEAR 2010

Table 2[2]: Top Management Challenges (2003-2010 in \%)

\begin{tabular}{|l|c|c|c|c|c|c|c|c|}
\hline ISSUE & 03 & 04 & 05 & 06 & 07 & 08 & 09 & 10 \\
\hline $\begin{array}{l}\text { Creating an } \\
\text { engaged work } \\
\text { force }\end{array}$ & 47 & 48 & 48 & 53 & 54 & 58 & 57 & 50 \\
\hline $\begin{array}{l}\text { Performance } \\
\text { management }\end{array}$ & na & na & na & na & na & na & na & na \\
\hline $\begin{array}{l}\text { Selecting and } \\
\text { Retaining key } \\
\text { Client }\end{array}$ & 55 & 55 & 53 & 57 & 62 & 50 & 39 & 45 \\
\hline $\begin{array}{l}\text { Managing } \\
\text { Change }\end{array}$ & na & na & na & na & na & na & na & na \\
\hline $\begin{array}{l}\text { Reducing Cost } \\
\text { Developing }\end{array}$ & 58 & 49 & 50 & 45 & 43 & 38 & 52 & 43 \\
\hline $\begin{array}{l}\text { Potential Leaders } \\
\text { Pustomer }\end{array}$ & 46 & 45 & 41 & 41 & 48 & 38 & 39 & 37 \\
\hline $\begin{array}{l}\text { Loyalty } \\
\text { Aligning Culture } \\
\text { with Strategy }\end{array}$ & na & na & na & na & na & na & na & na \\
\hline $\begin{array}{l}\text { Succession } \\
\text { Planning }\end{array}$ & 32 & 31 & 32 & 36 & 25 & 29 & 31 & 29 \\
\hline $\begin{array}{l}\text { Communicating, } \\
\text { Vision Mission } \\
\text { Values }\end{array}$ & 39 & 44 & 35 & 39 & 26 & 22 & 25 & 27 \\
\hline
\end{tabular}




\section{KEY ISSUES}

\section{A. Human Resource Development for the Past Few Years}

\section{- Workplace Diversity}

According to Thomas (1992)[4], dimensions of workplace diversity include, but are not limited to: age, ethnicity, ancestry, gender, physical abilities/qualities, race, sexual orientation, educational background, geographic location, income, marital status, military experience, religious beliefs, parental status, and work experience.

The future success of any organizations relies on the ability to manage a diverse body of talent that can bring innovative ideas, perspectives and views to their work. The challenge and problems faced of workplace diversity can be turned into a strategic organizational asset if an organization is able to capitalize on this melting pot of diverse talents. With the mixture of talents of diverse cultural backgrounds, genders, ages and lifestyles, an organization can respond to business opportunities more rapidly and creatively, especially in the global arena (Cox, 1993) [4], which must be one of the important organizational goals to be attained. More importantly, if the organizational environment does not support diversity broadly, one risks losing talent to competitors.

\section{- $\quad$ Challenges in Literacy Level}

Literacy in India is key for socio-economic progress, and the Indian literacy rate grew to $68 \%$ in 2007 from $12 \%$ at the end of British rule in 1947.According to the latest survey by the National Sample Survey Office (NSSO) in June 2008, the literacy rate among the population with age 7 and above was $72 \%$ whereas the adult population (age15 and above) had a literacy rate of $66 \%$. Although this was a greater than fivefold improvement, the level is well below the world average literacy rate of $84 \%,[3]$ and India currently has the largest illiterate population of any nation on earth. Despite government programs, India's literacy rate increased only "sluggishly," and a 1990 study estimated that it would take until 2060 for India to achieve universal literacy at thencurrent rate of progress. The 2001 census, however, indicated a 1991-2001 decadal literacy growth of $12.63 \%$, which is the fastest-ever on record.

\section{- $\quad$ Challenges in Entrepreneurship}

A recent Mckinsey \& Company-Nasscom report estimates that India needs at least 8,000 new businesses to achieve its target of building a US\$87 billion IT sector by 2008 . Similarly, in the next 10 years, 110-130 million Indian citizens will be searching for jobs, including 80-100 million looking for their first jobs. This does not include disguised unemployment of over $50 \%$ among the 230 million employed in rural India. Since traditional large employers-including the government and the old economy player-may find it difficult to sustain this level of employment in future, it is entrepreneurs who will create these new jobs and opportunities.

Today's knowledge based economy is fertile ground for entrepreneurs, in India. It is rightly believed that India has an extraordinary talent pool with virtually limitless potential to become entrepreneurs. Therefore, it is important to get committed to creating the right environment to develop successful entrepreneurs. To achieve this, India must focus on four areas.

The above issues are the tip of an ice berg, as we progress through the talk, we should never forget the advantages we have

\section{- $\quad$ Riding on the Positive Aspects}

a. India has been considered to be one of the fastest developing nations after independence

b. The talent pool available in India is one of the best in the world

c. People have passion for business, job, arts, innovation and excellence

d. Technological advancement and developmental adoption has been every fast

India has the fastest growing telecom network in the world with its high population and development potential. Airtel, Idea, Reliance, BSNL, Aircel, Tata Indicom, Vodafone, MTNL, and Loop Mobile are other major operators in India. However, rural India still lacks strong infrastructure. India's public sector telecom company BSNL is the 7th largest telecom company in world. Telephony introduced in India in 1882. Today the total number of telephone subscribers in the country crossed the 600 million mark in July 2010 and the total numbers of telephone subscribers have reached 688.38 million at the end of July 2010 The overall tele-density has increased to $58.17 \% \%$ in July 2010. In the wireless segment, 16.92 million subscribers have been added in July 2010.

The total wireless (GSM, CDMA \& WLL (F)) subscribers' base is 652.42 million as of July 2010. The wire line segment subscriber base stood at 35.96 million. According to recent reports, India will overtake China to become the world's largest mobile telecommunications market by the year 2013. It is predicted that by then, the tele density will shoot up to $75 \%$ and the total mobile subscriber base would be a staggering 1.159 billion [3].

- Economic development and purchase behavior of people have seen tremendous upward trend over the recent years.

- Steps taken by Government State and central has a major role in spite of odds faced by the government from time to time.

\section{THE SOLUTION}

With a bird's eye view of research on this topic and taking into account the economic progress, we can fine tune certain areas to arrive at a feasible solution to manage Developmental Challenges for $21^{\text {st }}$ Century.

\section{A. Create the Right and Realistic Environment for Success}

At all levels whether it is education, entrepreneurship, the cause and effect relationship should play a pivotal role in determining the success. People should be given skill based and value based training at all levels this will enhance their ability to take implementation based decisions rather than theoretical decision. Learn through action concept should be strengthened at all levels. 


\section{B. Co Development}

Out of many factors for the above issue, one of the key factor would be lack of co development, we should agree that the rapid change, the science technology field saw over the past few years was phenomenal compared to human competence development to handle technological change, For example there are still villages without basic facilities, still people who fear over computer, still mind sets unwilling to accept change.

\section{Value and Culture Development}

Individuals should start defining themselves on the parameters of self introspected value than materialistic value, societal view of judging a person merely with money and status should be suspended and individuals should look at another individuals to create an entity only by understanding his/her values.

People should start defining themselves their goals, their ideas, their action should originate from a self developed command and they should fine tune themselves to accept any results based on their action.

\section{QUOTING}

Mathew Arnold, who studied extensively the nexus between culture and literature on one hand and development on the other, recorded his observations in the timeless publication, Culture and Anarchy (1869).

Culture, he defined as a study of perfection, not merely as a way of life, which we are so mechanically used to in Ghana: "It is a study of perfection. It moves by the force, not merely or primarily of the scientific passion for the pure knowledge, but also of the moral and social passion for the doing good."

\section{A. The Ability to View Long Term than Short Term}

Survival even though becomes prima facie people have to develop a desire for long term. Many youth today are going behind the concept of live and enjoy for today, as we are progressing toward national development people should focus on long term goals which will help them stream line their action and results.

\section{B. Use of Technology to Take Right Roads which Will Lead to Right Path}

The technological advancement on one end is creating wonders and on the other end is creating blunders, growing cyber crimes, psychological diffusion resulting in improper behavior, influence of media and, artificial simulations leading the environment to witness a major catastrophe at all levels. The organizations should take this factor into account should guide/mentor their employees as how they should use technology for their advantage and organization's growth.

\section{CONCLUSION}

After careful analysis of the positive influence and negative consequences of the above explained topic the human resources of our country should undergo a value based transformation which will focus on sustained Human Resource Development with key focus on productive, passionate and positive development, their by reducing risk from threats like insecurity, uncertainty, technological adversity and economical disparity.

\section{COURTESY}

Table: 1

"Courtesy Ministry of Higher Education, Department of Higher Education, Ministry of Human Resources Government of India http://www.education.nic.in/sector.asp"

2. What's your organization's outlook for 2010 given the current economy?

"Courtesy: 2010 Research Findings, Klen Blanchard company's annual corporate issues findings"

"Courtesy Ministry of Higher Education, Department of Higher Education, Ministry of Human Resources Government of India http://www.education.nic.in/sector.asp"

Table: 2

"Courtesy: 2010 Research Findings, Klen Blenchard company's annual corporate issues findings"

Challenges in literacy level:

http://en.wikipedia.org/wiki/Literacy_in_India

\section{REFERENCES}

[1] http://en.wikipedia.org/wiki/Literacy_in_India

[2] 2010 Research Findings, Klen Blenchard company's annual corporate issues findings" http://en.wikipedia.org/wiki/List_of_countries _by_number_of_mobile_phones_in_use"

[3] http://en.wikipedia.org/wiki/Telecommunications_Statistics_in_India

[4] Rose Mary Wentling, Nilda Palma-Rivas, "Current status and future trends of diversity initiatives in the workplace: Diversity experts' perspective "Human resource development quarterly", Vol. 9, No. 3, Pp. 235-253, Autumn (Fall) 1998.

[5] "Maxwell Maltz Publication, Psycho Cybernetics", Pp: 55-80, 1969, Pocket Books, New York.

[6] Jayadayal Goenka, Sri Mad Bahgavad Gita 2005, Gita Press, Khorakpur David E .Golderberg, Life Skills and Leadership for Engineers 1995,Tata Mc Graw Hill. 